\title{
The role of brand equity in increasing buying interest
}

\section{Gita Sugiyarti $^{a^{*}}$ and Aris Mardiyono ${ }^{a}$}

${ }^{a}$ Faculty of Economics and Business University August 17, 1945 Semarang, Indonesia

\begin{tabular}{l}
\hline C H R O N I C L E \\
\hline Article history: \\
Received: December 10, 2020 \\
Received in revised format: \\
January 202021 \\
Accepted: March 16, 2021 \\
Available online: \\
March 16, 2021 \\
\hline Keywords: \\
Brand awareness \\
Brand image \\
Brand equity \\
Sales promotion \\
Consumer buying interest
\end{tabular}

\section{A B S T R A C T}

This study aims to analyze the effect of brand awareness, brand image and sales promotion on brand equity and consumer buying interest. The population of this study was all Swalayan Ada customers in Indonesia. The sample was taken by 550 respondents. After processing with normalization of data, the sample is worth using as many as 265 respondents. Analysis tools using Structural Equation Modeling with AMOS 16 program. The findings show that brand awareness, brand image and sales promotion have a significant positive effect on consumer buying interest. Brand image and sales promotion and brand equity have a significant positive effect on buying interest while brand awareness has no significant effect on consumer buying interest.

(C) 2021 by the authors; licensee Growing Science, Canada

\section{Introduction}

Globalization conditions require companies to compete with each other in marketing and selling products (Jussani et al., 2018). The right strategy can keep the product consumed by consumers continuously (Kuncoro \& Suriani, 2018). Creating new customers and retaining old customers must be done by the company continuously in order to keep selling in the market (Badi, 2018). Marketing is not only selling goods or services, but also a process where the activities include the creation of products or services, offering and handing them over to consumers (Dellaert, 2019). In addition communication is important to maintain the product (Melewar et al., 2017). Promotion is a form of marketing communication which includes marketing activities that attempt to disseminate information, persuade / influence, and remind target markets so that the product can be accepted, adapted to what is offered. (Fatoki, 2014).

Marketing strategy is a promotional strategy (Morgan et al., 2019). The company not only promotes the functional attributes of the product, but must be associated with the brand which is an important factor in introducing the product to consumers (Foster, 2016). Product brand associations can be attached to consumers (Goh \& Noor, 2019). By owning a brand, the product will be more easily known by consumers and as a tool to distinguish one product from another (Hernandez-Fernandez $\&$ Lewis, 2019).

Brand equity is an asset (Wood, 2000). Brand equity can have a positive impact on the company because the company knows the brand name is responded to by consumers (Karbasia \& Radb, 2014). For example, high brand equity is known to lead to high consumer buying and purchasing power (Raut, Pawar, Brito, \& Sisodia, 2019b). Brands are very important, especially in increasingly sharp brand competition conditions (Budaca \& Baltadora, 2014). The company is increasingly aware of the importance of the brand for the success of a product (Radzi et al., 2017; Farizan et al., 2019). Therefore, brand management

\footnotetext{
* Corresponding author.

E-mail address: gitaayuaris@gmail.com (G. Sugiyarti) 
strategy activities, including brand creation, building brands, expanding brands to strengthen the brand's position on competition (Hakala, Latti, \& Sandberg, 2011).

This research is based on the research gap between sales promotions to buying interest. There is a significant positive influence of the research (Hareka \& Wahyudi, 2020) and supported by Martinu and Anggraini (2018) and Hanaysha (2018). Instead there are those who find it insignificant among sales promotions against buying interests (Ruswanti \& Hapsari, 2019). Based on the background of the problem and the research gap, a research problem arises, namely: how is the effect of sales promotion on brand equity in increasing consumer buying interest?

\section{Literature Review}

\subsection{Brand Awareness}

Brand awareness is defined as the ability of a potential buyer to recognize / recall a brand as part of a product category (Stojanovic, Andreu, \& Curras-Perez, 2018b). Brand awareness is the dimension of brand equity (Raut, Pawar, Brito, \& Sisodia, 2019a). Brand awareness is the ability of a person who is a potential buyer to recognize or recall a brand that is part of a product category (Lee \& Workman, 2015).

According to Goh and Noor (2019), brand awareness consists of four categories: 1. Unwire of brand, including brands that remain unknown even though they have been reminded through mentoring; 2. Brand Recognition, this category includes product brands that are known to consumers after being reminded. 3. Brand Recall, this category includes products that are mentioned or remembered by consumers without having to do a recall; 4. Top of Mind, the brand name that was first published by consumers and is the top of the consumer's mind. (PrasantiRutha, Bakhtiar, \& Kirbrandoko, 2019) stated that brand awareness creates values, namely: A new product or service is definitely directed to get an introduction. Brand awareness indicators include: knowing the existence of a brand, recognizing the existence of a brand, given the presence of a brand, can mention the brand (Stojanovic, Andreu, \& Curras-Perez, 2018).

\subsection{Brand Image}

Brand image is an important aspect of a brand and can be based on reality or fiction depending on how consumers perceive it. The brand image is distinguished by 2, namely the association brand and charm (Zhang, 2015). Brand associations help understand benefits brands that consumers receive and the brand persona is a description of the brand in the contact of human characteristics, it helps understand the strengths and weaknesses of the brand (French \& Smith, 2019). Brand trust will form a brand image, where the brand image for consumers will vary depending on the brand experience consisting of the influence of selective perception, selective distortion and selective preferences (Sharma \& Jain, 2019). Brand image tends to systematically memory about brands that contain a target market interpretation of product attributes, benefits, situations, users and company characteristics (Kaur \& Kaur, 2019). Furthermore, brand image consists of brand knowledge and consuming situations such as evaluation of feelings and emotions associated with the brand.

Brand image is a complex symbol that has 6 levels of meaning or understanding: 1. Attributes are brands that are reminiscent of certain attributes (Zhang, 2015). 2. Benefits: attributes to be functional and emotional benefits, 3 . Value, the brand states the value of the procedure. 4. Culture, the brand symbolizes the country's culture, efficient and of high quality. 5. Personality. 6. User: brand implies the type of consumer who uses the product. (Kaur \& Kaur, 2019). Attributes, benefit attributes, pride, trust are indicators of brand image.

\subsection{Sales promotion}

Promotion is one of the components in the marketing mix which is often called the 4Ps (Salmana et al., 2017). Promotional activities are carried out in various ways to introduce products to target markets through various possible media. According to Genchev and Todorova (2017), sales promotion is a marketing activity other than personal selling, advertising and publicity that encourages consumer buying and retailer effectiveness, these activities include demonstrations, shows and exhibitions, and so on. The activities carried out in collaboration with the promotion of other activities and also easy in the company and personal selling. Promotions is used as one of the determining factors for the success of marketing programs as a series of processes of delivering product information offered by companies whose purpose is to influence as well as persuade consumers to make purchases and have loyalty to the product. Sales promotion is commonly used by companies to stimulate the process of purchasing products in increasing the number of sales with various incentives that have been compiled as a process of persuading consumers directly. (Low \& Barnes, 2012) explained that there are two types of sales promotion tools often used by companies, namely monetary promotion and non-monetary promotion that have different influences on the sale, profit, or brand equity of a company (Ramezani \& Heidarzadeh, 2014). Monetary promotion can be in the form of price discounts and coupons, in addition to providing a decrease in the perception of quality and brand image (Montaner \& Pina, 2008), it is also considered that discounted products are indicated as low quality products (Jakpar, Na, Johari, \& Myint, 2012). Conversely, non-monetary promotions in the form of prizes, free samples, and sweepstakes as non-pricing factors become an important strategy run by the company to increase brand equity (Mongkol, 2014). 
Companies carry out sales promotions aimed at attracting consumers and providing information in helping consumers make decisions to buy products or services. Promotion has both a short-term sales effect and a long-term brand equity effect (Guitart, Gonzalez, \& Stremersch, 2018). With sales promotion, companies seek to create value in the minds of consumers. The creation of a brand's good value causes consumers to remember the brand so that it will increase equity. (Burkhart, Krumeich, Werth, \& Loos, 2011), suggests being identified as important issues. According to Arifianti (2016), sales promotion indicators include discounted prices, coupons, lotteries, prizes, vouchers.

\subsection{Brand Equity}

Brand equity is the added value of a product and service (Kim \& Lee, 2018; Bravo Gil \& Salinas, 2007; Joo-Eon Jeon, 2017). Brand equity is the positive differential effect of having knowledge of the brand name on a product or service. The brand equity of a product will attract customers to show preference for products that have a brand rather than unbranded products even though they are basically identical. Brand equity can provide value and benefits, both for consumers and for companies (Hussain, Mu, Mohiuddin, and, \& Sair, 2020): 1. Consumer value, a. Brand equity is useful for consumers to interpret, process and store large amounts of information about products and brands. b. Confidence in consumers in making purchasing decisions, both because of the experience of the past in its characteristics. c. Perception of quality and brand association can strengthen consumer satisfaction with the experience of using it. 2. Value to the company a. strengthen the program lure new consumers or re-embrace old consumers. b. perception of quality, brand associations and other brand assets are able to strengthen brand loyalty, i.e. can provide reasons to buy and influence usage satisfaction, c. gets higher margins by allowing optimum prices and reducing dependence on promotions. d. provides the foundation for growth through brand expansion. e. provides the foundation for growth through brand expansion. f. provides encouragement in distribution channels. g. Equity assets are a competitive advantage that poses a real barrier to competitors.

Brand image indicator according to Joo-Eon Jeon (2017) is choosing a brand over other similar brands, brand quality is better than other brands, loyalty to the brand.

\subsection{Buying Interest}

A consumer in search of satisfaction will look for information about products (Garcia, Freire, Santos, \& Andrade, 2020). If the needs of the consumer are strong and the object he is looking for can meet the needs as desired then the consumer will buy the product. Zhang et al. (2020) stated several stages of psychological purchase behavior. These stages include: attention, interest, desire, decisions, and behavior to buy.

According to Boutang (2016), interest is one of the psychological aspects that affects behavior and becomes a source of motivation to direct someone to do an activity or action. Purchase interest is a psychological activity that arises because of feelings and thoughts about a desired product or service. The interest in buying can be interpreted as a happy attitude towards an object that makes the individual seek to obtain the object by paying it with money or sacrifice (Lee, 2019). According to Albari and Safitri (2018) purchase interest can be said to be the stage of the respondent's tendency to act before the purchase decision is made.(Pe na-García, Gil-Saura, Rodríguez-Orejuela, \& Siqueira-Junior, 2020) said that the buying interest is different from the intention to buy, the intention to buy is a no further than the consumer's buying interest where the confidence to decide to buy is already in a large percentage. Purchase intention is the final level of buying interest in the form of trust before a purchase decision is made. (Nawi, Mamun, Nasir, and, \& Mustapha, 2019) , indicators of buying interest are: 1. Transactional interest, the tendency to buy products. 2. Referential interest, a person's tendency to refer products to others. 3. Preferential Interests, interests that describe the behavior of a person who has a primary preference for the product. Preferences can only be changed if something happens to the product you like. 4. Exploratory interest, describes the behavior of a person seeking information about a product to support the positive properties of the product.

\section{Hypothesis}

\subsection{Relationship of brand awareness with brand equity}

The ability of prospective buyers to recognize, considering that the brand is part of the product category, is called brand awareness (Lee, Goh, \& Noor, 2019). Brand awareness has a role in brand equity, depending on the extent of awareness achieved by a brand (Joo-Eon Jeon, 2017). The role of brand awareness in overall brand equity depends on the extent and extent of awareness achieved by a brand (Raut et al., 2019a). Brand awareness means the ability of a prospective buyer to recognize or remember a particular brand and product category,(Noorlitaria A, Pangestu, Fitriansyah, Untung Surapati, \& Mahsyar, 2020), (Shahid, Hussain, \& aZafar, 2017). The role of brand awareness in overall brand equity depends on the extent of awareness achieved by a brand (Stojanovic et al., 2018a). (Jeong, 2003) in research on brand image influence and brand awareness on liquid milk brand equity in Frisian flag packaging, the results of the analysis showed that brand awareness has a significant positive influence on brand equity. (Świtała, Gamrot, Reformat, \& Bilińska-Reformat, 2018) in research on The influence of brand awareness and brand image on brand equity - an empirical study of logistics service providers, the results of the analysis showed that brand awareness has a significant positive influence on brand equity. From the review of the results of the above research can be drawn hypotheses as follows: 


\subsection{Brand image relationship with brand equity}

Brand equity is something characterized as an intangible asset and an inherent value of a well-known brand. Consumers are willing to pay more for brands that hold high brand equity due to the attractiveness/brand image inherent in the product. Brand image relates to a combination of influence from brand associations, consumer perception of tangible and intangible brands, outlining unique, strong and preferred associations (Gill \& Dawra, 2010). A unique, strong and preferred brand image will put the brand in a strategic position in consumer memory thus increasing brand equity (Emari, Jafari, \& Mogaddam, 2012). Brand equity requires a brand that is familiar and positive in the eyes of consumers (Rajh \& Došen, 2009). Companies should always pay attention to increasing brand value in brand image development (Amron, 2018). If a brand is known and in the minds of consumers means there is brand association and product differentiation characterized by the perception of high quality impacting on customer satisfaction, customer loyalty and ultimately producing high brand equity. Good brand image management can overcome marketing problems because the brand image focuses more on the psychological aspects of consumers that are difficult to imitate by competitors. (Lee, James, \& Kim1, 2014), The brand image is reflected by the brand itself into memory when consumers see the brand. The brand image is constructed from several sources including brand experience and product category, product attributes, price information, position on promotional communications, user imagination, and conditions of use. (Ebrahim, Ghoneim, Irani, \& Fan, 2016). The research findings (Emari et al., 2012), the mediation effect of brand loyalty and brand image on brand equity, shows that brand image has a significant positive effect on brand equity. (Świtała et al., 2018) examining the effect of brand awareness and brand image on brand equity shows that brand image has a significant positive effect on brand equity. Based on the above research, the following hypothesis can be proposed,

\section{$\mathrm{H}_{2}$ : Brand Image has a positive influence on Brand Equity.}

\subsection{Sales promotion relationship with brand equity}

Sales promotion aims to attract consumers and provide information to help consumers make decisions to buy a product or service (Chaharsoughi \& Hamdard, 2011). Through sales promotion, the company seeks to create value in the minds of consumers (Liu, Zhang, Huang, Zhang, \& Zhao, 2020), between advertising and sales promotion there is a difference, advertising 'buy our products', is being a sale and purchase promotion now. Through sales promotions, consumers are expected to be able to respond quickly to buy a product or service (Ofosu-Boateng, 2020). Furthermore, according to (Abdullah, Hanaysha, \& Abdghani, 2017), Building short-term relationships with consumers is especially effective when using sales promotions

Karbasia and Radb (2014) explained that a company can increase brand equity with sales promotions. The marketing mix element is one of the sales promotions. (Thabit \& Raewf, 2018). In his research, Joo-Eon Jeon (2017) states that marketing information affects brand equity through its dimensions, namely price, sales promotion, and advertising. (Abdullah et al., 2017). The results of Mongkol's (2014) research marketing communication, influenced the creation of brand equity. Another factor that can increase brand equity is by conducting marketing activities including sales promotions. On the basis of the above description submitted the 3 rd hypothesis is

\section{$\mathrm{H}_{3}$ : Sales Promotion has a significant positive effect on brand equity.}

\subsection{Brand awareness's relationship with buying interests}

Knowledge of brand awareness will affect consumer buying interest (Yamawati \& Indiani, 2019). Consumers will tend to buy products with well-known brands compared to products whose brands are still foreign to their ear. Buying interest is also based on consumer knowledge they obtain from the information media about the brand of the product. The results of Świtała et al. (2018) also stated that the higher the level of awareness of a person's brand, the consumer's buying interest in products with the brand increases because the brand is the first one he remembers. On the basis of the above thoughts, the hypothesis is formulated as follows;

\section{$\mathrm{H}_{4}$ : Brand Awareness has a significant positive effect on buying interest.}

\subsection{Relationship between Brand Image and buying interests}

(Haghshenas et al., 2013) states that a brand that is known to buyers will generate interest in making purchasing decisions. The impact of product symbols provides meaning in decision making because symbols or images are important in advertising and affect consumer buying interest. In a previous study compiled by Rezvani et al. (2012) who examined the effect of consumer purchase interest, it was found that brand image affects consumer purchase interest. The relationship between brand image and purchase intention is stated (Soenyoto, 2015) direct effect on the high interest in buying a product Based on the above thinking, the following hypothesis is formulated; 
$\mathrm{H}_{5}$ : Brand Image has a positive and significant effect on Buying Interest.

\section{Research Method}

\subsection{Sample and data collection procedures}

Data collection by survey, including primary data and secondary data. The research questions consisted of brand awareness, brand image, sales promotion, brand equity and buying interest related to quantitative research. The quantitative data uses the structural equation model (SEM), version 16.0. Samples of 550 customers Swalayan Ada in Semarang, Kudus, Pati, Bogor Indonesia. The selection of respondents is determined by purposive sampling method with certain considerations and criteria, including respondents who are self-service customers, have used products and services in the last 3 months with a minimum of 10 transactions $\geq 17$ years old, and knowing the promotional programs that have been held and sponsored by Swalayan Ada. Then data normality is carried out, while data processing is feasible for a number of 265.

\subsection{Research Variables}

Variable operationalization is seen in table 1 below:

Table 1

Variable operationalization

\begin{tabular}{|c|c|c|c|}
\hline Variable & Core Meaning & Operational Measures & Source \\
\hline Brand Awareness & $\begin{array}{l}\text { Brand awareness is the } \\
\text { ability of a prospective } \\
\text { buyer to recognize or } \\
\text { recall that a brand is part } \\
\text { of a particular product } \\
\text { category }\end{array}$ & $\begin{array}{l}\text { 1. Knowing the existence of brands } \\
\text { 2.Recognizing the presence of brands } \\
\text { 3. Given the presence of brands } \\
\text { 4.Can mention the brand }\end{array}$ & Igor, 2017 \\
\hline Brand Image & $\begin{array}{l}\text { A representation of the } \\
\text { overall perception of } \\
\text { the brand and is shaped } \\
\text { by the information and } \\
\text { past experience of the } \\
\text { brand }\end{array}$ & $\begin{array}{l}\text { 1. The existence of attribute } \\
\text { 2. Benefits of attribute } \\
\text { 3. Pride } \\
\text { 4. Trust }\end{array}$ & Harsandaldeep, 2019 \\
\hline Sales Promotion & $\begin{array}{l}\text { An activity to draw } \\
\text { attention to a particular } \\
\text { product in the short term }\end{array}$ & $\begin{array}{l}\text { 2. Lottery } \\
\text { 3. Coupon } \\
\text { 4. Gift } \\
\text { 5. Voucher }\end{array}$ & Ria, 2017 \\
\hline Brand Equity & $\begin{array}{l}\text { Added value given } \\
\text { to products and services }\end{array}$ & $\begin{array}{l}\text { 1. Choose brand } \\
\text { 2. Brand quality } \\
\text { 3. Quality perception }\end{array}$ & Noorshella, 2019 \\
\hline $\begin{array}{l}\text { Buying } \\
\text { Interest }\end{array}$ & $\begin{array}{l}\text { A concept to measure a } \\
\text { company's marketing } \\
\text { achievements }\end{array}$ & $\begin{array}{l}\text { 1. Transactional interest } \\
\text { 2. Referential interest } \\
\text { 3. Preferential interest } \\
\text { 4. Exploratory interest }\end{array}$ & Joan Eon,2016 \\
\hline
\end{tabular}

Source : Igor, 2017, Harsandaldeep, 2019, Ria, 2017, Noorshella, 2019, Joan Eon,2016

\subsection{Results and discussions}

\subsubsection{Data Screening}

Social research, data is difficult to distribute normally (Hair, 2011), it is necessary to normalize the data. (Cain, Zhang, \& Yuan, 2017) For positive direction data, the skewness is changed by $1 / \mathrm{X}$. From the top $1 / \mathrm{X}$ formula, series data are generated with a normal distribution pattern. Analyzes were carried out if normalized. The sample indicator is less than 0.6 then these items should be removed from the analysis. All AVE values of each variable are above the required value 0.5 . As shown in Table 2, the data can be explained reliably because the construct reliability value of each variable is greater than the cut-off $(>0.60)$. 
Table 2

Scale \& Measurement - Construct Validity

\begin{tabular}{|c|c|c|c|c|}
\hline Indicator Variables & Source & $\begin{array}{l}\text { Factor } \\
\text { Loading }\end{array}$ & AVE & CR Composite Reliability \\
\hline Brand Awareness & Igor, 2017 & & 0.67 & 0.79 \\
\hline 1. Knowing the existence of brands & & 0.71 & & \\
\hline 2. Recognizing the presence of brands & & 0.76 & & \\
\hline 3. Given the presence of brands & & 0.66 & & \\
\hline 4. Can mention the brand & & 0.69 & & \\
\hline Brand Image & Harsandaldeep, 2019 & & & \\
\hline 1. Can mention the brand & & 0.71 & & \\
\hline 2. Benefits of attribute & & 0.82 & & \\
\hline 3. Pride & & 0.81 & & \\
\hline 4. Trust & & 0.67 & & \\
\hline Sales Promotion & & & 0.72 & 0.74 \\
\hline 1. Discount price & Ria, 2017 & 0.81 & & \\
\hline 2. Lottery & & 0.67 & & \\
\hline 3. Lottery & & 0.76 & & \\
\hline 4. Gift & & 0.67 & & \\
\hline 5. Voucher & & 0.87 & & \\
\hline Brand Equity & Noorshella, 2019 & & 0.79 & 0.76 \\
\hline 1. Choose brand & & 0.78 & & \\
\hline 2. Brand equity & & 0.81 & & \\
\hline 3. Quality perception & & 0.79 & & \\
\hline Buying Interest & Joan Eon, 2016 & & 0.73 & 0.72 \\
\hline 1. Transactional interest & & 0.72 & & \\
\hline 2. Referential interest & & 0.73 & & \\
\hline 3. Transactional interest & & 0.72 & & \\
\hline 4. Exploratory interest & & 0.73 & & \\
\hline
\end{tabular}

Source: Processed primary data, 2020

\subsubsection{Structural Model Analysis (SEM)}

Hypothesis testing using SEM-AMOS in Full Structural Models is seen in Table 3, with two steps of hypothesis testing. The first step of the researchers tested the goodness of fit seem basic criteria with chi-square significance level $(\mathrm{s} 2)=95,754$, significance level $=0.023 ; \mathrm{DF}=235 ; \mathrm{GFI}=.925 ; \mathrm{AGFI}=.903 ; \mathrm{CFI}=0.983 ; \mathrm{TLI}=0.955 ; \mathrm{RMSEA}=0.063, \mathrm{CMIN} / \mathrm{DF}=$ 1.148. It is concluded that the model is fit. Second, testing the causal relationship between variables using CR criteria equal to or greater than 2.0 (Arbuckle 2012). From the results of processed data found as follows.

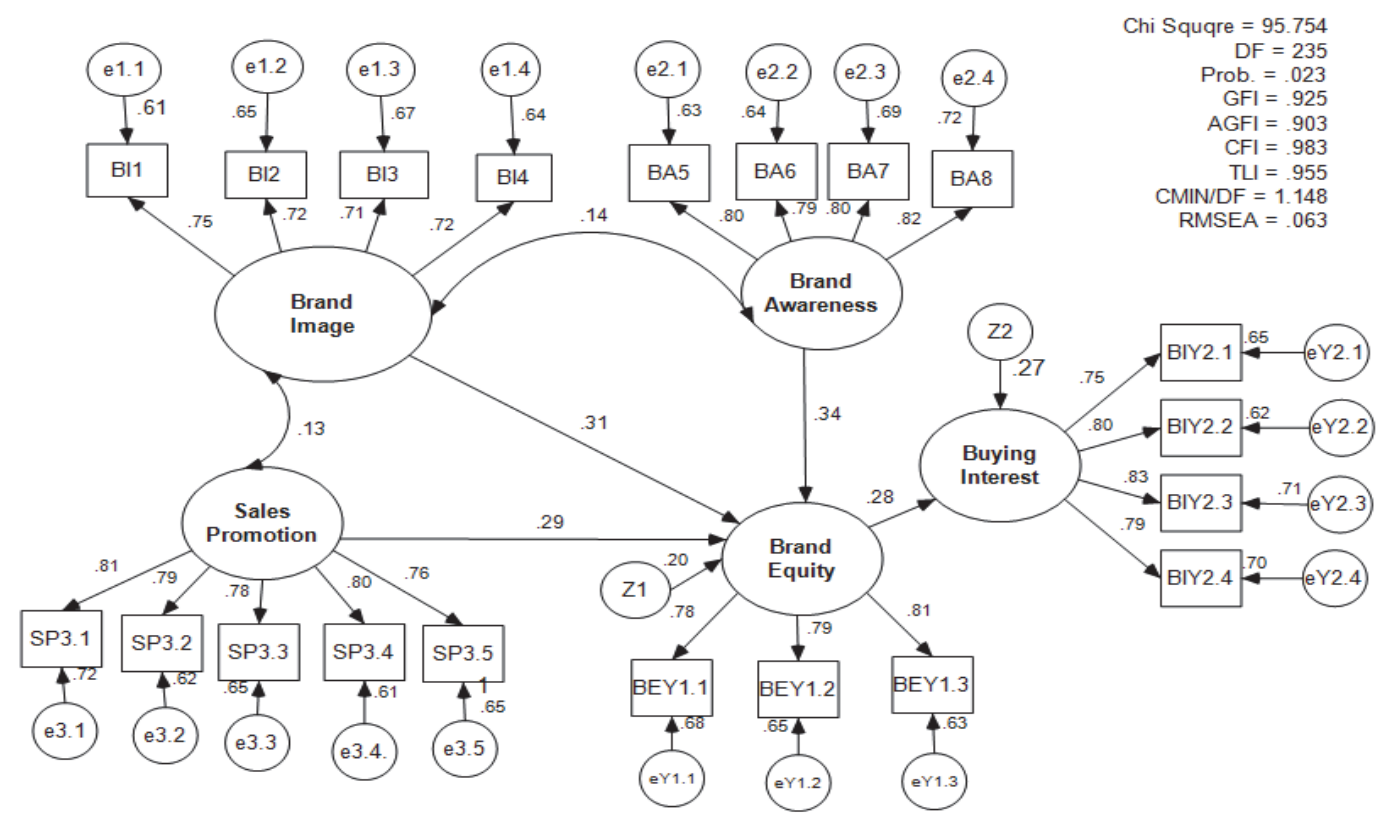

Fig. 1. Full Structural Model

Parameter Assessment Results from Research Model 
Table 3

Hypothesis Testing

\begin{tabular}{lcccc}
\hline & Estimate & S.E & C.R & P \\
\hline Brand Equity $\rightarrow$ Brand Awareness & 0.551 & 0.088 & 3.765 & $* * * *$ \\
Brand Equity $\rightarrow$ Brand image & 0.432 & 0.134 & 2.896 & 0.002 \\
Brand Equity $\rightarrow$ Sales promotion & 0.552 & 0.133 & 2.954 & $* * *$ \\
Buying interest $\rightarrow$ Brand Awareness & 0.442 & 0.143 & 1.555 & 0.031 \\
Buying interest $\rightarrow$ Brand Equity & 0.533 & 0.133 & 2.799 & 0.002 \\
\hline
\end{tabular}

\subsection{Discussion}

The first hypothesis states that brand awareness has a significant positive effect on brand equity, accepted. Process data found $\mathrm{CR}$ value in the relationship between brand awareness variable in brand equity seen in table 3 is CR of 3.765 , with P value of ***. Both cr eligible values are above 1.96 and $\mathrm{P}$ is below 0.05 . It can be concluded that the first hypothesis proves significant, that brand awareness directly affects brand equity means that the higher the brand awareness, the higher the brand equity. These findings provide positive confirmation on the results of previous studies (Świtała et al., 2018; Jeong, 2003) gave an indication of the importance of brand awareness to encourage brand equity. It can be explained that brand equity is a brand power that promises the value that consumers expect for a product so that eventually consumers feel more satisfaction when compared to other products. Brand equity will give consumers confidence in making purchasing decisions, both because of past experience in characteristics. A minimarket will have value or strength at a time when the level of consumer awareness of the Swalayan Ada is increasing. Brand awareness can be a signal of the presence, commitment, and substance of a brand product. If a brand can be recognized, there must be a reason, such as: the company has advertised widely, the company has been in business for quite a while, the distribution range is wide, and the brand is successful. The equity of a retail business will be formed due to the behavior of consumers who prefer shopping in Swalayan Ada. This is because consumers assume that shopping at a convenience store will have its own pride. In addition, consumers are also more interested in the attributes on products offered in Swalayan ada, including accurate product size, neat packaging, cleanliness, comfort, security, and adequacy of public facilities provided. The results of this study expanded the study conducted by (Noorlitaria et al., 2020) and (Shahid et al., 2017) found evidence that brand awareness affects brand equity.

The second hypothesis states that brand image has a significant positive effect on brand equity, accepted. The result of the data found cr value in the relationship between brand image variables in brand equity seen in Table 3 is CR of 2.896 , with P value of 0.002 . Both cr eligible values are above 1.96 and $\mathrm{P}$ is below 0.05 . It can be concluded that the second hypothesis proves significant, that the brand image directly affects the brand equity means that the higher the brand image, the higher the brand equity. This means that brand image has long been known as an important concept in marketing, so it can be concluded that brand image plays an important role in brand development. Brand image can create brand equity either directly or indirectly (Emari et al., 2012) found that brand image has a positive and significant influence on brand equity. Brand image is a very important component for consumer decision making and evaluation of a particular brand (Świtała et al., 2018), so it can be concluded that brand image contributes in building brand equity.

The third hypothesis states that sales promotions have a significant positive effect on brand equity, accepted. Found the result of CR value of sales promotion influence on brand equity seen in table 3 is CR of 2954, with $\mathrm{P}$ value of ***. Both cr eligible values are above 1.96 and $\mathrm{P}$ is below 0.05 . It can be concluded that the third hypothesis proves significant, that sales promotion directly affects brand equity means that the higher the sales promotion, the higher the brand equity. To increase brand equity through sales promotions (Karbasia \& Radb, 2014), companies need to make efforts to attract people to visit Swalayan Ada, one of which is through sales promotions. The sales promotion that has been done by this Swalayan Ada has attracted enough public interest, such as a direct discount of $10 \%$ and a voucher of $20 \%$. For some visitors, the requirement to get a voucher is quite expensive, namely by buying goods for Rp. 200.000 ,- to get 10 vouchers with a discount of $20 \%$ for the purchase of all products. Another discount offer is necessary, as has been done by other Swalayan Ada, both foreign and local.

The fourth hypothesis states that brand awareness has a significant positive effect on buying interest, rejected. Found the result of CR value influence of brand awareness on buying interest seen in table 3 is CR of 1.555 , with a value of $P$ of 0.031 , thus $\mathrm{H} 4$ is rejected, meaning the higher the brand awareness of a product then does not increase the interest in consumer resending. (Świtała et al., 2018) explained that brand awareness is a common communication goal for all promotional strategies. The existence of brand awareness is assumed that the brand of a product will be embedded in the mind of consumers so that it also affects the buying interest. The results showed that consumer awareness about the brand of products in Swalayan Ada does not affect consumer memory to generate buying interest for consumers. The results of this study do not support previous research conducted by (Yamawati \& Indiani, 2019), with the results of brand awareness has a significant positive effect on re-purchase interest. But the results of this study according to namely brand awareness have no significant effect on re-buying interest.

More about this source text Source text required for additional translation information. The fifth hypothesis states that brand equity has a significant positive effect on purchase intention, accepted. It is found that the effect of the value of CR value of brand equity on purchase intention is shown in table 3 which is a $\mathrm{CR}$ of 2.779 , with a $\mathrm{P}$ value of 0.002 , meaning that the 
higher the brand equity, the more consumer interest in making repeat purchases. (Rezvani et al., 2012) argues that Brand Equity is the added value provided to products and services that can be reflected in the way consumers think, feel, and act in relation to brands, as well as the price, market share, and profitability that brands provide to companies. So when the way people think, feel and act about the brand of products in Swalayan Ada increases then by itself will increase the Buying Interest in the product. This result also supports research conducted by Agusli and (Haghshenas et al., 2013) entitled Analysis of The Influence of Brand Equity on Consumer Buying Interest. The study stated that Brand Equity variables have a significant influence on Buying Interest. This is also in line with research conducted by (Rezvani et al., 2012) entitled the influence of Brand Equity on Purchase Interest and its Impact on Purchasing Decisions stating that the Buy Interest variable has a significant effect on purchasing decisions. Based on the opinion of experts and researchers, it can be concluded that brand equity owned Swalayan Ada is high. This is indicated by the respondent's high answer value. The results of the study of all indicators on equity variables. The results of the value obtained showed that a lot of consumers tend to see the brand in Swalayan Ada is a well-known brand and from these results proved to influence so as to stimulate consumers' Buying Interest.

\section{Conclusion}

The results of the five hypotheses can be concluded:

The first hypothesis, the influence of brand awareness on brand equity, is accepted. Where the indicator of brand awareness knows the existence of the brand, recognizing the existence of the brand, given the presence of the brand, can mention the brand. The results showed that indicators can mention brands have the most influence among other indicators. Indicators are carried out based on literature review and developed according to the state of the Swalayan Ada. In this study found brand awareness increases brand equity.

The second hypothesis is that the influence of brand image on brand equity is accepted. Where the indicators of the brand image are the existence of attributes, benefits of attributes, pride, trust. The results showed that trust indicators had the most influence among other indicators. Indicators are carried out based on literature review and development of Swalayan Ada. In this study found brand image increases brand equity.

The third hypothesis, the influence of sales promotion on brand equity is accepted. Where indicators of sales promotions are discount prices, coupons, lottery, prizes, vouchers. The results showed that price discount indicators had the most influence among other indicators. Indicators are carried out based on literature review and developed according to Swalayan Ada. In this study found sales promotion increases brand equity.

The fourth hypothesis, the influence of brand awareness on buying interest is rejected. Where the indicator of brand awareness knows the existence of the brand, recognizing the existence of the brand, given the presence of the brand, can mention the brand. The results showed that all indicators have very little influence. Indicators are carried out based on literature review and developed according to the state of the Swalayan Ada. In this study found brand awareness does not increase buying interest.

The fifth hypothesis, the influence of brand equity on buying interest is accepted. Where the indicator of brand equity knows awareness of brand, brand image, perception of quality. The results showed that brand image indicators have the most influence among other indicators. Indicators are carried out based on literature review and developed according of Swalayan Ada. In this study found brand equity increases consumer buying interest.

\subsection{Managerial implications}

To increase buying interest, then:

First, companies need to make efforts to increase consumer awareness of Supermarkets. This can be done through promotion and marketing communications. For example, through advertising that can be done to introduce this existing supermarket to the public. Attractive outlet arrangement to attract people to visit Ada Supermarket.

Second, the Company needs to maintain and improve the image of Swalayan Ada, through improving the quality of both services and products.

Third, companies, especially if they want to open outlets in other cities, need to look at the characteristics of the surrounding communities. Based on the literature study on the concept of brand equity mentioned that a person has a perception of Swalayan Ada s depending on the level of education, social and economic class. Therefore, it is necessary to pay attention to the characteristics of the community in the city or region concerned before deciding to open a new branch or outlet in an area. 


\subsection{Limitations of research}

First, this study initially distributed questionnaires as many as 550 exemplars, but due to discrepancies in the results of the model output when respondents answered the questionnaire, then in the end the questionnaire that was worthy to be analyzed further amounted to 265 , while the other 35 questionnaires were declared flawed, due to the presence of some respondents who answered extreme so that this study produced an unexpected data output.

Second, there is one hypothesis that is rejected in this study, namely hypothesis 4 which reads the higher the brand awareness, the higher the buying interest.

\subsection{Future research}

Future research agenda, related to research samples. This study used 550 respondents as the study population, after the normality of the data, 265 respondents were ready to process the data, but in further research it is necessary to add objectives to increase the generalization of the research results. In addition, future research should use a sample that is considered more representative of the research population so that it can increase the generalizability of the research results.

\section{Reference}

Abdullah, H. h., Hanaysha, J., \& Abdghani, N. H. (2017). Analyzing the relationship between advertising and sales promotion with brand equity. Asian International Journal of Social Sciences, 17(2), 88 - 103. doi: 10.29139/aijss.20170204

Albari, \& Safitri, I. (2018). The Influence of Product Price on Consumers' Purchasing Decisions. Review of Integrative Business and Economics Research, Vol. 7, Supplementary Issue 2, 7(2), 328-337.

Amron, A. (2018). The Influence of Brand Image, Brand Trust, Product Quality, and Price on the Consumer's Buying Decision of MPV Cars. European Scientific Journal, 14(13), 228-239. doi: 10.19044/esj.2018.v14n13p228

Arifianti, R. (2016). Sales Promition of Hypermart in Bandung City, West Java, Indonesia. Review of Integrative Business and Economics Research, 5(2), 304-311.

Badi, K. S. A. (2018). The Impact of Marketing Mix on the Competitive Advantage of the SME Sector in the Al Buraimi Governorate in Oman. journals.sagepub.com/home/sgo, PP.1-10. doi: 10.1177/215824401880083

Boutang, J. (2016). Risk marketing. Journal of Centrum Cathedra: The Business and Economics Research Journal, 9(1), 2751. doi: 10.1108/JCC-08-2016-0008

Budaca, C., \& Baltadora, L. A. (2014). Brand Communication Challenges in Getting Young Customer Engagement. Procedia Economics and Finance, 16(2014), 521 - 525. doi: 10.1016/S2212-5671(14)00833-8

Burkhart, T., Krumeich, J., Werth, D., \& Loos, P. (2011). Analyzing The Business Model Concept- A Comprehensive Classification Of Literature. Thirty Second International Conference on Information Systems, Shanghai.

Cain, M. K., Zhang, Z., \& Yuan, K.-H. (2017). Univariate and multivariate skewness and kurtosis for measuring nonnormality: Prevalence, influence and estimation. Behav Res, 2017(49), 1716-1735.

Chaharsoughi, S. A., \& Hamdard, J. (2011). The Affect Of Sales Promotion On Consumer Interest To Purchase In IKCO Automotive Company. Journal of Knowledge Management, Economics and Information Technology, 2011(4).

Dellaert, B. G. C. (2019). The consumer production journey: marketing to consumers as co-producers in the sharing economy. Journal of the Academy of Marketing Science, 47, 238-254. doi: https://doi.org/10.1007/s11747-018-0607-4

Ebrahim, R., Ghoneim, A., Irani, Z., \& Fan, Y. (2016). A brand preference and repurchase intention model: the role of consumer experience. Journal Of Marketing Management, 32(13-14), 1230-1259. doi: 10.1080/0267257X.2016.1150322

Emari, H., Jafari, A., \& Mogaddam, M. (2012). The mediatory impact of brand loyalty and brand image on brand equity. African Journal of Business Management, 6(17), 5692-5701. doi: 10.5897/AJBM11.788

Farizan, N., Rohman, F., \& Hussein, A. S. (2019). The Effect Of Brand Identity, Brand Image, And Perceived Value On Loyalty With Customer Satisfaction As Mediation Variable For Costumer Fresh Juice Bintaro. Journal of Applied Management (JAM), 17(1). doi: http://dx.doi.org/10.21776/ub.jam. 2019.017.01.14

Fatoki, O. (2014). The Entrepreneurial Intention of Undergraduate Students in South Africa: The Influences of Entrepreneurship Education and Previous Work Experience. Mediterranean Journal of Social Sciences, 5(7), $294-299$.

Foster, B. (2016). Impact of Brand Image on Purchasing Decision on Mineral Water Product “Amidis" (Case Study on Bintang Trading Company). American Research Journal of Humanities and Social Sciences, 2(2016), PP/1-11.

French, A., \& Smith, G. (2019). Measuring Brand Association Strength: A Consumer Based Brand Equity Approach. Loughborough University Business School, Loughborough University, Loughborough, Leicestershire LE11 $3 T U$, UK. figshare. https://hdl.handle.net/2134/14786., 1-20. doi: http://dx.doi.org/10.1108/03090561311324363

Garcia, J. M., Freire, O. B. D. L. o., Santos, E. B. A., \& Andrade, J. (2020). Factors affecting satisfaction and loyalty to online group buying. Revista de Gest ao, 27(3), 2020. doi: 10.1108/REGE-02-2018-0037

Genchev, E., \& G.Todorova. (2017). Sales Promotion Activities - Effective Tool Of Marketing Communication Mix. Trakia Journal of Sciences, 15(1), pp 181-185, 2017. doi: 10.15547/tjs.2017.s.01.033

Gill, M. S., \& Dawra, J. (2010). Evaluating Aaker' s sources of brand equity and the mediating role of brand image. Journal of Targeting, Measurement and Analysis for Marketing, 18(3/4), 189-198. 
Goh, J. E. L. a. M. L., \& Noor, M. N. B. M. (2019). Understanding purchase intention of university students towards skin care products. PSU Research Review, 3(3), 161-178. doi: 10.1108/PRR-11-2018-0031

Guitart, I. A., Gonzalez, J., \& Stremersch, S. (2018). Advertising non-premium products as if they were premium: The impact of advertising up on advertising elasticity and brand equity. International Journal of Research in Marketing, 35(2018), 471-489. doi: https://doi.org/10.1016/j.ijresmar.2018.03.00

Haghshenas, L., Abedi, A., Ghorbani, E., Kamali, A., \& Harooni, M. N. (2013). Review consumer behavior and factors affecting on purchasing decisions. Singaporean Journal of Business, Economics and Management Studies, 51(1112), 1-8.

Hair, J., Ringle, C., \& Sarstedt, M. (2011). PLS-SEM: Indeed a Silver Bullet. Journal of Marketing Theory and Practice, 19(2011), 139-151. doi: https://doi.org/10.2753/MTP1069-6679190202

Hakala, U., Latti, S., \& Sandberg, B. (2011). Operationalising brand heritage and cultural heritage. Journal Of Product \& Brand Management, 20(6), 447-456. doi: 10.1108/10610421111166595]

Hanaysha, J. R. (2018). An examination of the factors affecting consumer's purchase decision in the Malaysian retail market. PSU Research Review, 2(1), 7-23. doi: 10.1108/PRR-08-2017-0034

Hareka, J. A., \& Wahyudi, A. (2020). The Relationship Between Consumer Doubt And Value For Money On Purchase Intention. Review of Management and Entrepreneurship, 4(1), 1-16.

Hernandez-Fernandez, A., \& Lewis, M. C. (2019). Brand authenticity leads to perceived value and brand trust. European Journal of Management and Business Economics, 28(3), 222-238. doi: 10.1108/EJMBE-10-2017-0027

Hussain, I., Mu, S., Mohiuddin, M., and, R. Q. D., \& Sair, S. A. (2020). Effects of Sustainable Brand Equity and Marketing Innovation on Market Performance in Hospitality Industry: Mediating Eects of Sustainable Competitive Advantage. Sustainability, 12(2939), 1-19. doi: 10.3390/su12072939

Jakpar, S., Na, A. G. S., Johari, A., \& Myint, K. T. (2012). Examining the Product Quality Attributes That Influences Customer Satisfaction Most When the Price Was Discounted: A Case Study in Kuching Sarawak. International Journal of Business and Social Science, 3(23), 221-236.

Jeong, H.-b. K. W. G. K. (2003). The effect of consumer-based brand equity on firms' financial performance. Journal of Consumer Marketing, 20(4), 335 - 351. doi: http://dx.doi.org/10.1108/07363760310483694

Joo-Eon Jeon. (2017). The impact of brand concept on brand equity. Asia Pacific Journal of Innovation and Entrepreneurship, $11(2), 233-245$.

Jussani, A. C., Eduardo Pinheiro Gondim de Vasconcellos, and, J. T. C. W., \& Grisi, C. C. d. H. e. (2018). Marketing internationalization: influence factors on product customization decision. RAUSP Management Journal, 53(4), 555-574. doi: 10.1108/RAUSP-07-2018-0043

Karbasia, B. J., \& Radb, A. J. (2014). The effect of sales promotions characteristics on brand equity. Management Science Letters, 4(2014), 2107-2116. doi:

Kaur, H., \& Kaur, K. (2019). Connecting the dots between brand logo and brand image. Asia-Pacific Journal of Business Administration, 11(1), 68-87. doi: 10.1108/APJBA-06-2018-0101

Kim, H.-K., \& Lee, T. J. (2018). Brand Equity of a Tourist Destination. Sustainability, 10(431), 1-21. doi: $10.3390 /$ su10020431

Kuncoro, W., \& Suriani, W. O. (2018). Achieving sustainable competitive advantage through product innovation and market driving. Asia Pacific Management Review, 23(2018), 186-192. doi: http://dx.doi.org/10.1016/j.apmrv.2017.07.006

Lee, J. E., Goh, M. L., \& Noor, M. N. B. M. (2019). Understanding purchase intention of university students towards skin care products. PSU Research Review, 3(3), 161-178. doi: 10.1108/PRR-11-2018-0031

Lee, J. L., James, J. D., \& Kim1, Y. K. (2014). A Reconceptualization of Brand Image. International Journal of Business Administration, 5(4). doi: 10.5430/ijba.v5n4p1

Lee, S.-H., \& Workman, J. E. (2015). Compulsive buying and branding phenomena. Journal of Open Innovation: Technology, Market, and Complexity, 1(3), 1-12. doi: 10.1186/s40852-015-0004-X

Lee, S. Y. a. J. (2019). The Effects of Consumers' Perceived Values on Intention to Purchase Upcycled Products. Sustainability, 11(1034). doi: 10.3390/su11041034

Liu, Q., Zhang, X., Huang, S., Zhang, L., \& Zhao, Y. (2020). Exploring Consumers' Buying Behavior in a Large Online Promotion Activity: The Role of Psychological Distance and Involvement. Journal of Theoretical and Applied Electronic Commerce Research, 15(1), 66-80. doi: 10.4067/S0718-18762020000100106

Low, B., \& Barnes, B. R. (2012). Consumer Perceptions of Monetary and Nonmonetary Introductory Promotions for New Products. Journal of Marketing Management, 28(5-6), 629-651. doi: 10.1080/0267257X.2011.560889

Martinu, H., \& Anggraini, L. (2018). The Effect Of Sales Promotion In Social Media On The Students: Purchase Intention Of Face Cleaner Water Product. Humaniora, 9(1), 15-22.

Melewar, T. C., Foroudi, P., Gupta, S., \& Kitchen, P. J. (2017). Integrating identity, strategy and communications for trust, loyalty and commitment. European Journal of Marketing, 51(3), 572-604. doi: 10.1108/EJM-08-2015-0616

Mongkol, K. (2014). Integrated Marketing Communication to Increase Brand Equity: The Case of a Thai Beverage Company. International Journal of Trade, Economics and Finance, 5(5), 445-448.

Montaner, T., \& Pina, J.-M. (2008). The Effect Of Promotion Type And Benefit Congruency On Brand Image. The Journal of Applied Business Research, 24(3), 15-28.

Morgan, N. A., Whitler, K. A., Feng, H., \& Chari, S. (2019). Research in marketing strategy. Journal of the Academy of Marketing Science, 47(1), 4-29. 
Nawi, N. B. C., Mamun, A. A., Nasir, N. A. M., and, A. A., \& Mustapha, W. N. W. (2019). Brand image and consumer satisfaction towards Islamic travel packages A study on tourism entrepreneurship in Malaysia. Asia Pacific Journal of Innovation and Entrepreneurship, 13(2), 188-202. doi: 10.1108/APJIE-02-2019-0007

Noorlitaria, G., Pangestu, F. R., Fitriansyah, U. S., \& Mahsyar, S. (2020). HOW DOES BRAND AWARENESS AFFECT PURCHASE INTENTION IN MEDIATION BY PERCEIVED QUALITY AND BRAND LOYALTY?. Journal of Critical Reviews, 7(2), 103-109.

Ofosu-Boateng, I. (2020). Influence of Consumer Sales Promotion on Consumers' Purchasing Behaviour of the Retailing of Consumer Goods in Tema, Ghana. Journal Of Marketing Management, 8(1), 24-36. doi: 10.15640/jmm.v8n1a4

Pe na-García, N., Gil-Saura, I., Rodríguez-Orejuela, A., \& Siqueira-Junior, J. e. R. (2020). Purchase intention and purchase behavior online: A cross-cultural approach. Heliyon, 6(2020), 1-11. doi: https://doi.org/10.1016/j.heliyon.2020.e04284

PrasantiRutha, N. L. P. E., Bakhtiar, T., \& Kirbrandoko. (2019). The Brand Ambassador Effectivenesson Brandimage Andpurchasing Decision For Oppo Fseries Smartphone. International Journal of Business and Management Invention (IJBMI), 8(3), PP 44-50.

R. Bravo Gil, E. F. A. s., \& Salinas, E. M. n. (2007). Family as a source of consumer-based brand equity. Journal Of Product \& Brand Management, Journal of Product \& Brand Management (3), 188-199. doi: 10.1108/10610420710751564

Radzi, K. M., Nor, M. N. M., \& Ali, S. M. (2017). The Impact Of Internal Factors On Small Business Success: A Case Of Small Enterprises Under The Felda Scheme. Asian Academy of Management Journal, 22(1),, 22(1), 27-55. doi: https://doi.org/10.21315/aamj2017.22.1.2

Rajh, E., \& Došen, Đ. O. (2009). The Effects of Marketing Mix Elements on Service Brand Equity. Economic ResearchEkonomska Istraživanja, 22(4), 69-83. doi: 10.1080/1331677X.2009.11517392

Ramezani, M. R., \& Heidarzadeh, K. (2014). The Impact Of Monetary And Non-Monetary Promotions On Brand Equity In Industrial Market (Case Study: "Iranpotk" Company). International Journal of Research In Social Sciences, 3(5), 1-13.

Raut, U. R., Pawar, P. A., Brito, P. Q., \& Sisodia, G. S. (2019a). Mediating model of brand equity and its application. Spanish Journal of Marketing -ESIC, 23(2), 295-318. doi: 10.1108/SJME-04-2019-0021

Raut, U. R., Pawar, P. A., Brito, P. Q., \& Sisodia, G. S. (2019b). Mediating model of brand equity and its application. Spanish Journal of Marketing -I, 23(2),

295-318. doi: 10.1108/SJME-04-2019-0021

Rezvani, S., Dehkordi, G. J., Rahman, M. S., Mahsa, F. F., Habibi, \& Eghtebasi, S. (2012). A Conceptual Study on the Country of Origin Effect on Consumer Purchase Intention. Asian Social Science, 8(12), 205-2014. doi: 10.5539/ass.v8n12p205

Ruswanti, E., \& Hapsari, N. P. (2019). Analysis Advertising, Sales Promotion, Personal Selling And Direct Selling On Purchase Intention Vegetables In Retail West Jakarta. Advances in Economics, Business and Management Research, 10, 657-662.

Salmana, D., YasserTawfi, Samyc, M., \& Artal-Turd, A. (2017). A new marketing mix model trescue the hospitality industry: Evidence from Egypt after the Arab Spring. Future Business Journal, 13(2017), 47-69. doi: http://dx.doi.org/10.1016/j.fbj.2017.01.004

Shahid, Z., Hussain, T., \& aZafar, F. (2017). The Impact of Brand Awareness on The consumers' Purchase Intention. Journal of Marketing and Consumer Research, 33(2017).

Sharma, R., \& Jain, V. (2019). CSR, Trust, Brand Loyalty and Brand Equity: Empirical Evidences from Sportswear Industry in the NCR Region of India. Metamorphosis, 18(1), 57-67. doi: 10.1177/0972622519853158

Soenyoto, F. L. (2015). The Impact of Brand Equity on Brand Preference and Purchase Intention in Indonesia's Bicycle Industry: A Case Study of Polygon. iBuss Management, 3(2), 99-108.

Stojanovic, I., Andreu, L., \& Curras-Perez, R. (2018a). Effects of the intensity of use of social media on brand equity An empirical study in a tourist destination. European Journal of Management and Business Economics, 27(1), 83-100. doi: 10.1108/EJMBE-11-2017-0049

Świtała, M., Gamrot, W., Reformat, B., \& Bilińska-Reformat, K. (2018). The influence of brand awareness and brand image on brand equity - an empirical study of logistics service providers. Journal of Economics and Management, 33(3), 96119. doi: $10.22367 /$ jem.2018.33.06

Thabit, T. H., \& Raewf, M. B. (2018). The Evaluation of Marketing Mix Elements: A Case Study. International Journal of Social Sciences \& Educational Studies, 4(4). doi: 10.23918/ijsses.v4i4p100

Wood, L. (2000). Brands and brand equity: definition and management. Management Decision, 38/9 [2000], $38(9)$, 662-669.

Yamawati, S., \& Indiani, N. L. P. (2019). The Influence of Brand Equity on Consumer Interest in Buying Xiaomi Smartphones. Warmadewa Management and Business Journal (WMBJ), 1(2), 60-64. doi: http://dx.doi.org/10.22225/wmbj.1.2.1249.60-64

Zhang, J., Zheng, W., \& Wang, S. (2020). The study of the effect of online review on purchase behavior Comparing the two research methods. International Journal of Crowd Science, 4(1), 73-86. doi: 10.1108/IJCS-10-2019-0027

Zhang, Y. (2015). The Impact of Brand Image on Consumer Behavior: A Literature Review. Open Journal of Business and Management, 2015(3), 58-62. doi: http://dx.doi.org/10.4236/ojbm.2015.31006 
(C) 2021 by the authors; licensee Growing Science, Canada. This is an open access article distributed under the terms and conditions of the Creative Commons Attribution (CC-BY) license (http://creativecommons.org/licenses/by/4.0/). 